\title{
Do Store Atmosphere and Perceived Value Matter in Satisfying and Predicting the Millennials' Behavioral Intention in a Café Setting?
}

\author{
Martinus Fieser Sitinjak ${ }^{1}$; Christian Haposan Pangaribuan²; Nabila Tafriza ${ }^{3}$ \\ ${ }^{1,3}$ Management Department, BINUS Business School Undergraduate Program, Bina Nusantara University \\ Jln. K. H. Syahdan No. 9, Jakarta Barat 11480, Indonesia \\ ${ }^{2}$ Faculty of Business, Sampoerna University \\ Jl. Raya Pasar Minggu No.Kav. 16, Jakarta Selatan 12780, Indonesia \\ ${ }^{1}$ msitinjak@binus.edu; ${ }^{2}$ christian.pangaribuan@sampoernauniversity.ac.id; ${ }^{3}$ bellatfrz@gmail.com
}

Received: $17^{\text {th }}$ January 2019/ Revised: $13^{\text {th }}$ March 2019/ Accepted: $12^{\text {th }}$ April 2019

How to Cite: Sitinjak, M. F., Pangaribuan, C. H., \& Tafriza, N. (2019). Do Store Atmosphere and Perceived Value Matter in Satisfying and Predicting the Millennials' Behavioral Intention in a Café Setting? Binus Business Review, 10(1), 31-40. https://doi.org/10.21512/bbr.v10i1.5345

\begin{abstract}
The purpose of this research was to determine the effects of store atmosphere and perceived value on customer satisfaction and its impact on behavioral intention on the millennial segment. This type of research was a quantitative method using associative research approach and Partial Least Squares Structural Equation Modeling (PLS-SEM) methods measured by Smart-PLS 3.0. The distribution of questionnaires was a non-probability with simple random sampling. The survey was conducted to 200 college students between the ages of 17 and 30 at a café in a shopping mall in Jakarta in 3 months (December 2017 until February 2018). The result shows that the store atmosphere can be used to generate perceived value, customer satisfaction, and behavioral intention. However, store atmosphere is confirmed to be the main behavioral intention predictor directly and indirectly.
\end{abstract}

Keywords: store atmosphere, perceived value, millennial generation, behavioral intention

\section{INTRODUCTION}

Despite being a developing country in ASEAN, Indonesia is currently the $18^{\text {th }}$ largest economy in the world and is experiencing a remarkable economic growth after the Asian Financial Crisis in the late 1990s (Indonesia Investments, 2016). As a developing country, there are varieties of industries that are rapidly nurtured in Indonesia. Industrialization prompts to the direct result of economic growth, which further develops a process of urbanization in both developed countries and newly industrialized ones (Chen, Zhang, Liu, \& Zhang, 2014). The rapid growth of population and the increased number of millennials have pushed the rise of urbanization since the monetary crisis in 1997, which in turn disrupt urban migration (McCarthy, 2003). With urbanization, young millennials have the urge to generate impacts through their venturing in urban environments (Dibley, Clark, \& Myers, 2016;
Cohen \& Muñoz, 2015). It leads to the increase of value in the food service industry. Millennials, born between 1982 and 2000, are considered to be one of the groups with massive annual consumer spending and to have vast spending power (Solomon, Bamossy, Askegaard, \& Hogg 2014). Hence, it is why they are chosen as the main research object.

The foodservice industry plays a conducive role in the country's economy (Ellen, Anantadjaya, $\&$ Saroso, 2014). Indonesia plays a significant role in having the highest foodservice sales amongst other ASEAN countries and has a steady growth. From 2010 to 2014 , it increased ten times on volume sales, and it was estimated to have at least valued at US\$39.906,4 million in 2015. According to Ong (2018), Indonesia amongst other ASEAN countries has received the highest percentage of sales value in the foodservice market such as eat-in outlets. Meanwhile, Thailand has received the lowest. Despite the diversity of these 
six ASEAN countries, there are a number of common trends developing across the whole region. Dining out becomes a lifestyle choice for many consumers in Southeast Asia especially on the millennial segment. Thus, it is about the experience of dining out like it is about the food itself (DeVaney, 2015; Moreno, Lafuente, Carreon, \& Moreno, 2017).

In light of the growth of eat-in sales, this growth can be described as the changing lifestyles of the millennials, who are slowly resuming their spending in this industry by indulging in prepared meals, rather than preparing it themselves (Saulo, 2016). Furthermore, the number of working mothers in Indonesia who used to be in charge of cooking at home has increased, so Indonesian families are dining out more often. Having customers accustomed to that kind of lifestyle, the foodservice industry in Indonesia grew at a Compound Annual Growth Rate (CAGR) of $8,7 \%$ from 2010 to 2014 , and it reached US\$36,8 billion in 2014 (Agriculture and Agri-Food Canada, 2016). Based on the data, full-service restaurants, cafés/bars, and fast food subsectors appear to be the top three growth drivers for Indonesia's foodservice sector. That is why café operators must place a high priority in understanding the local customers' preferences, especially for the millennials.

Due to the challenges in the foodservice industry, café operators need to investigate new ways of establishing and maintaining competitive advantage over rivals (Ivkov, Blešić, Simat, Demirović, \& Božić, 2016; Sabir, Irfan, Akhtar, Pervez, \& Rehman, 2014; Wade, Holmes, \& Gibbs, 2017). Meanwhile, to achieve these targets, these cafés not only compete with existing competitors in the market but also new competitors. Hence, customers have greater choice in choosing one café or switching to another. To create a positive behavioral intention, café operators always try to provide great services and different experience as much as possible. It takes more than food to influence attention towards a visitation. One of the ways is by focusing on the atmospheric effects of the café (Jalil, Fikry, \& Zainuddin, 2016b). The physical environment has been considered an essential subject in food service management because customers' emotional responses to a service environment are related to their consumption behaviors at the point of purchase (Hussain \& Ali, 2015; Jalil et al., 2016b). Considering the importance of the totality of the atmosphere and the physical environment in which a service setting is given, the atmosphere can play a significant role for the customers to notice something special (McGrath, Aronow, \& Shotwell, 2016). Customer satisfaction has long been considered a fundamental determinant of long-term customer behavior, so service firms increasingly dedicate their substantial energies to track customer satisfaction. Looking at the relationship between store atmospherics and perceived value, Jalil et al. (2016b) proposed that store atmospherics had a significant positive influence on perceived value. Perceived value affected customer satisfaction which created a significance for service operators to concentrate on the customer's perception towards the café to fulfill the expectations. It resulted in customer satisfaction. Hence, it is important for service management to understand how customers perceive the atmosphere and the attractiveness of the café that conveys different values to increase customer satisfaction. It can also create positive behavioral intentions because the customer is comfortable enough to behave towards the café positively.

Atmosphere refers to the aesthetics and ambiance of the store. The elements of the in-store environment include color, music, and crowd to reflect the store atmosphere. Atmospherics has been defined as how the design elements of a space are manipulated in order to create certain affective responses that the main sensory channels for atmosphere are sight, sound, scent, and touch (Ballantine, Jack, \& Parsons, 2010). In the marketing literature, several definitions have been revealed towards atmospherics. Themes and concepts have been utilized as a strategy to create a better ambiance (Ali \& Mubarak, 2016). It allows customers to visit a café. Moreover, Heung and $\mathrm{Gu}$ (2012) mentioned that favorable environments led to approach behavior, such as the desire/willingness to stay, explore and communicate.

According to Ryu, Han, and Kim (2008), there is a positive relationship between customer satisfaction and behavioral intention like stated by Jalil et al. (2016b). Then, the customer satisfaction is also given by atmosphere (Heung \& Gu, 2012) and perceived value (Kim \& Han, 2008; Raji \& Zainal, 2016; Joung, Choi, \& Wang, 2016). Therefore, to generate a behavioral intention, store atmosphere and perceived value are required with customer satisfaction as an intervening variable.

In the restaurant setting, based on Ryu and Jang (2008), the DINESCAPE can be used as a measurement scale for the physical environment of upscale restaurants. The DINESCAPE consists of six dimensions: facility aesthetics, ambiance, lighting, service product (table settings in particular), layout, and service staff. Facility aesthetics refers to the function of architectural design along with interior decoration. Ambiance represents intangible background characteristics including music, aroma, and temperature. Based on quantitative factor analysis, the layout dimension focuses on the seating arrangement of restaurants and measures the psychological properties like perceived crowdedness of the spatial layout. Finally, service staff reflects the social aspect of the service environment. It is measured by the attractiveness, a number of employees, and their grooming. Besides the aforementioned factors, the availability of Wi-Fi in the eating-place will definitely provide interaction and communication benefits to the potential customers to revisit (Jalil et al., 2016b). Previous researchers also show that the provision of free wireless communications and Wi-Fi networks access can contribute to a better customers' experience and satisfaction (El-Sherie \& Ghanem, 2016; Masri, Anuar, \& Yulia, 2017). 
According to Heung and $\mathrm{Gu}$ (2012), four aspects of restaurant atmospherics are identified as relevant to their current research. First, facility aesthetics includes interior design and decoration (Gogoi, 2017; Heung $\& \mathrm{Gu}, 2012)$. Second, ambiance includes background music, aromas in the dining room, lighting, and temperature (Cottet, Plichon, \& Lichtle, 2010). Third, spatial layout refers to how furnishings and fixtures are arranged in the dining area (Cho \& Lee, 2017). Fourth, employee factors consist of the appearance and number of restaurant employees (Skandrani, Ben Dahmane Mouelhi, \& Malek, 2011). Based on the literature as mentioned earlier, the availability of Wi-Fi is added to the list (Jalil, Fikry, \& Zainuddin, 2016a).

The key to building lasting customer relationships is to create superior customer value (Kotler \& Armstrong, 2014). This implies that when customers purchase a product, they expect to receive benefits greater than the costincurred. It further indicates that the higher the benefits obtained by customers are, the higher the level of customer satisfaction will be. Conversely, the lower the benefits customers get, the lower the level of customer satisfaction is. Given the increasingly competitive foodservice environment, the delivery of superior value to customers in an offering (product or service) enhances customer loyalty and eventually contributes to an overall improvement in a firm's financial performance (Belás, \& Gabčová, 2016). If the companies know what drives the value for their customers and provide superior customer value, they have a greater probability of obtaining and retaining customers (Magatef \& Tomalieh, 2015). Therefore, it can be noted that an in-depth understanding of customer value is very important for companies to succeed.

According to Fishbein and Ajzen (1975), the behavior of the intentions towards the products and services is the result in customer's perceived satisfaction with the products and services provided by the provider of products and services. Understanding customers' behavior will facilitate management in developing products or services according to the needs and desires of customers. The desire to behave is often based on the possibility of action to be performed (Javanmard, 2016). Behavioral intentions are considered to include revisit intention and wordof-mouth that can predict the future consumption behavior of the customers and their word-of-mouth recipients (Triantafillidou \& Siomkos, 2014).

Then, customers frequently develop an attitude towards purchasing based on prior service experience (Ryu \& Jang, 2008). This indicates that customers can develop an attitude based on prior information without actual experience. They frequently increase biases for or against providers based on the provider's images in the marketplace. The attitude is strongly related to the customer's intentions to repatronize the service or product and to be engaged in word-of-mouth behaviors.

Based on Jalil et al. (2016b), it is proposed that store atmospherics will have a significant positive influence on perceived value. The findings suggest that favorable atmosphere can be an additional marketing tool to maintain customers. This is also supported by Koshki, Esmaeilpour, and Ardestani (2014) by showing that the store atmosphere had a positive effect on perceived value. Thus, the first hypothesis is:

H1 : Store atmosphere has a significant positive influence on perceived value.

According to Heung and $\mathrm{Gu}$ (2012), the dimensions of store atmosphere have a significant influence on the customers' dining satisfaction. Shin, Hwang, Lee, and Cho (2015) also indicated that the store atmosphere had positive influences on customer satisfaction. The research concluded that customer satisfaction was affected by franchised coffee shops' store atmosphere affecting customers' loyalty. This is also supported by Petzer and Mackay (2014) and Tulipa, Gunawan, and Supit (2014). Based on the discussion, the second hypothesis is:

H2 : Store atmosphere has a significant positive influence on customer satisfaction.

Viewing the impact of store atmosphere on behavioral intentions, it is further noted that a favorable environment can motivate behavioral approaches (Heung \& Gu, 2012). Jalil et al. (2016b) mentioned that behavioral intentions were also regressed on perceived atmospherics. This is supported by Ali and Amin (2014) that their findings were consistent with previous research by identifying the role of the atmosphere on post-consumption behaviors. The third hypothesis is:

H3 : Store atmosphere has a significant positive influence on behavioral intentions to return.

Previous researchers mention that the improvement in quality, value, and satisfaction in a service encounter enhances favorable outcomes. According to Joung et al. (2016), the perceived value of campus foodservice is a good indicator for predicting customer satisfaction using the structural equation model. Cibro and Hudrasyah (2017) found that the perceived values of food quality, people and process, place, price, promotion, and the physical evidence had positive influences on customer satisfaction. The fourth hypothesis is:

H4 : Perceived value has a significant positive influence on customer satisfaction.

According to Githiri (2017), perceived value has a significant positive influence in the context of Kenyan rated restaurants. If the customer's overall assessment based on their perceptions of what is received from the service provider is not in accordance with their preferences, negative behavioral intentions 
are likely to be engaged in a certain behavior. Basaran and Buyukyilmaz (2015) also indicated a significant positive influence of perceived value on behavioral intention in the fast-food and fast-casual restaurant sector.

Furthermore, this idea is supported by Wahyuningsih (2011). The researcher mentioned the significant positive influence of perceived value on behavioral intention through customer satisfaction. Based on this discussion, the fifth hypothesis is:

H5 : Perceived value has a significant positive influence on behavioral intentions.

To create positive behavioral intentions, food service providers such as cafés should be able to make customers satisfied with their decision to choose the café. It is by comparing other cafés in providing an enjoyable comfort and experience that exceeds their expectations. The significant positive influence between customer satisfaction and behavioral intention is also supported by Cibro and Hudrasyah (2017) in the context of quick service restaurants. Therefore, the sixth hypothesis is:

H6 : Customer satisfaction has a significant positive influence on behavioral intentions.

Seeing the gap in understanding the behavior intentions of café customer, this research intends to observe the combined impacts of store atmospherics on customer satisfaction and behavioral intentions, and provide the empirical result based on the concept research. The specific objectives of this study are to determine whether there is a relationship between store atmosphere and perceived value, between store atmosphere and customer satisfaction; store atmosphere and behavioral intention; perceived value and customer satisfaction; perceived value and behavioral intention; and customer satisfaction and behavioral intention.

The research questions of this research are: (1) Does the store atmosphere have a significant positive influence on perceived value?, (2) Does the store atmosphere have a significant positive influence on customer satisfaction?, (3) Does the store atmosphere have a significant positive influence on behavioral intentions?, (4) Does perceived value have a significant positive influence on customer satisfaction?, (5) Does perceived value have a significant positive influence on behavioral intentions?, and (6) Does customer satisfaction have a significant positive influence on behavioral intentions?

\section{METHODS}

The method used in this research is a descriptive research. It uses Partial Least Squares Structural Equation Modeling (PLS-SEM) to investigate the effects of store atmosphere and perceived value on customer satisfaction and its impact on behavioral intention. The method conducted is a non-probability purposive sampling. Over a period from December 2017 to February 2018, the research was administered by distributing questionnaires directly to the college students visiting Amypond café in Pondok Indah shopping mall by asking them to fill out an online survey form. The minimum requirement of the sample is 100 based on the Taro Yamane formula (Akhamiokhor \& Adanikin, 2017). From 220 distributed questionnaires using Google Form link, only 200 responses are valid resulting in a response rate of $90,9 \%$.

The survey is built based on prior research which uses currently validated scales, such as Likerttype scales with the range of response options from "1=strongly disagree" to " $5=$ strongly agree". The original items are in English and are translated into Bahasa Indonesia. The measurement indicators can be seen in Tables $1-4$. The dimensions are adapted from previous researchers (Heung \& Gu, 2012; Sweeney \& Soutar, 2001; Rozekhi, Hussin, Siddiqe, Rashid, \& Salmi, 2016; Triantafillidou \& Siomkos, 2014). Then, SEM is utilized to test the hypotheses in the proposed structural model (Figure 1).

Table 1 Operational Variable for Store Atmosphere

\begin{tabular}{ll}
\hline Dimensions & Measurement Indicator \\
\hline Spatial Layout \& Employee & Seating arrangement \\
& Layout \\
& Employees uniform \\
& Plants/flowers \\
& Paintings/pictures \\
Ambiance & Temperature \\
& Aroma \\
& Lighting \\
& Interior design \\
Facility Aesthetics & Furniture quality \\
& Background music \\
View from the Windows & Window view \\
\hline
\end{tabular}

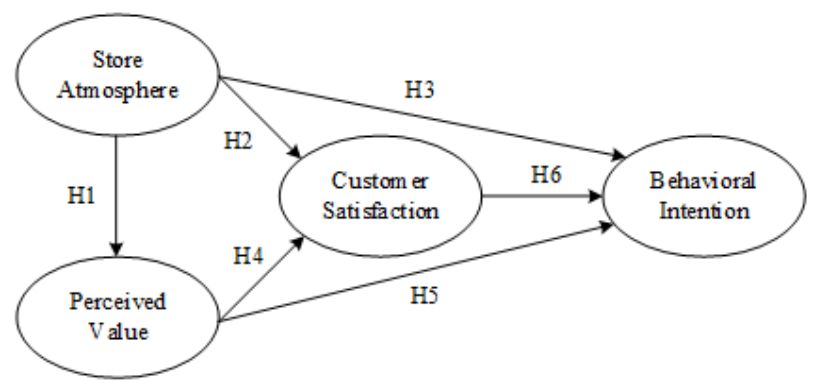

Figure 1 Conceptual Model of the Research 
Table 2 Operational Variable for Perceived Value

\begin{tabular}{ll}
\hline Dimensions & Measurement Indicator \\
\hline Quality Value & Quality \\
& Workmanship \\
& Consistent performance \\
Emotional Value & Enjoyable feeling \\
& Relaxing feeling \\
& Pleasurable \\
Price Value & Price reasoning \\
& Value for money \\
& Economical reasoning \\
Social Value & Perceived improvement \\
& Feeling of acceptance \\
& Feeling of good impression \\
& Approval from society \\
\hline
\end{tabular}

Table 3 Operational Variable for Customer Satisfaction

\begin{tabular}{ll}
\hline Dimensions & Measurement Indicator \\
\hline Satisfied/Unsatisfied & I am satisfied with the service \\
Pleased/Not Pleased & $\begin{array}{l}\text { I am pleased to have visited } \\
\text { I wappy/Unhappy }\end{array}$ \\
$\begin{array}{l}\text { experience } \\
\text { The café gives overall } \\
\text { Good/Bad Experience }\end{array}$ & $\begin{array}{l}\text { satisfaction and good } \\
\text { experience }\end{array}$ \\
\hline
\end{tabular}

Table 4 Operational Variable for Behavioral Intention

\begin{tabular}{|c|c|}
\hline Dimensions & Measurement Indicator \\
\hline \multirow[t]{2}{*}{ Re-experience Intention } & Re-experience consideration \\
\hline & Experience probability \\
\hline \multirow[t]{2}{*}{ WOM Intention } & Willingness to tell others \\
\hline & Willingness to recommend \\
\hline
\end{tabular}

\section{RESULTS AND DISCUSSIONS}

In this research, from 200 respondents, males are more than females $(52,50 \%)$. For monthly allowance, they have less than Rp1.000.000,00 (equivalent to US\$75). The majority of the respondents are living in Jakarta $(56,50 \%)$. The highest frequency of hanging out in a café is a week with $83,50 \%$. The demography of the respondents can be seen in Table 5 .
Table 5 Demography of the Respondents

\begin{tabular}{lll}
\hline Variable & Item & Frequency \\
\hline Gender & Male & $52,50 \%$ \\
& Female & $47,50 \%$ \\
Monthly Allowance & $<$ Rp1.000.000,00 & $58,50 \%$ \\
& Rp1.000.000,00- & $21,50 \%$ \\
& Rp2.000.000,00 & \\
& $>$ Rp2.000.000,00 & $20,00 \%$ \\
Place of Residence & Jakarta & $56,50 \%$ \\
& Tangerang & $33,50 \%$ \\
& Depok & $5,50 \%$ \\
& Bekasi & $4,50 \%$ \\
Hangout Frequency & Once a week & $83,50 \%$ \\
& Twice a week & $10,50 \%$ \\
& More than twice & $6,00 \%$ \\
\hline
\end{tabular}

The outer loading test in bootstrapping output shows that three indicators have a factor loading value below 0,5 . Those are SA08 (store atmosphere), PV06 (perceived value), and PV07 (perceived value). Therefore, a re-test by removing the three indicators are needed. The bootstrapping with the revised model are shown in Figure 2.

The standard test of Average Variances Extracted (AVE) for each variable must be higher than 0,5 to be considered valid. The results of AVE are shown in Table 6 . The variables are good to go to the next procedure.

Table 6 Average Variance Extracted (AVE) Results

\begin{tabular}{lc}
\hline Variable & $\begin{array}{c}\text { Average Variance } \\
\text { Extracted (AVE) }\end{array}$ \\
\hline Behavioral Intention & 0,670 \\
Customer Satisfaction & 0,733 \\
Perceived Value & 0,525 \\
Store Atmosphere & 0,532 \\
\hline
\end{tabular}

To use composite reliability in testing the reliability value, each variable must be greater than 0,7 . It is considered adequate for convergent validity (Hair, Hult, Ringle, \& Sarstedt, 2016). The results can be seen in Table 7.

Table 7 Composite Reliability Results

\begin{tabular}{lc}
\hline Variable & Composite Reliability \\
\hline Behavioral Intention & 0,889 \\
Customer Satisfaction & 0,917 \\
Perceived Value & 0,930 \\
Store Atmosphere & 0,925 \\
\hline
\end{tabular}




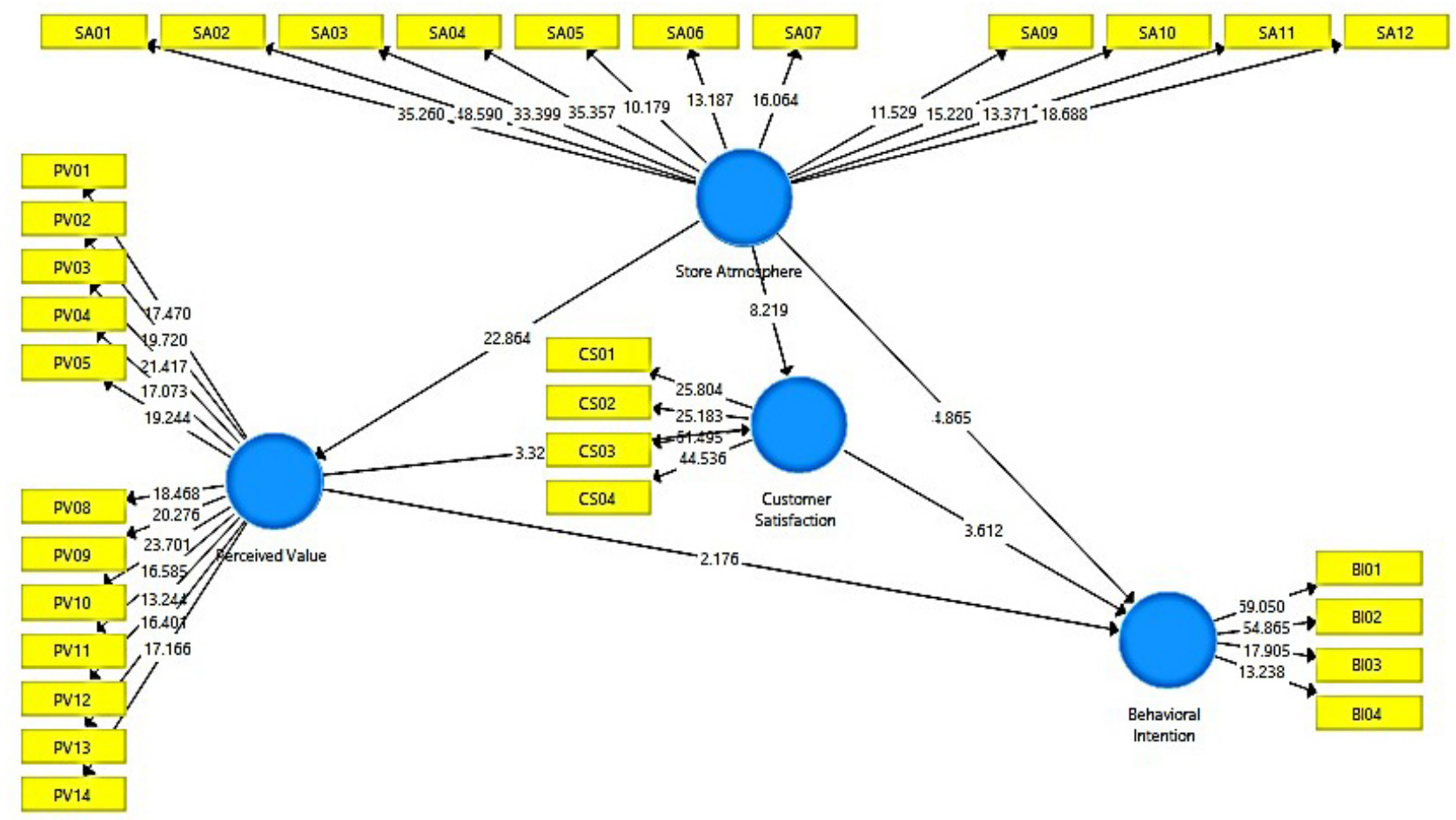

Figure 2 Bootstrapping Output

To use Cronbach's Alpha in testing the reliability value, each variable must be greater than 0,7 . Then, it will be considered acceptable (Ghozali \& Latan, 2015). Hence, the internal consistency between the items of each variable is secured. The result of composite reliability is shown in Table 8 .

Table 8 Cronbach's Alpha

\begin{tabular}{lc}
\hline \multicolumn{1}{c}{ Variable } & Cronbach's Alpha \\
\hline Behavioral Intention & 0,833 \\
Customer Satisfaction & 0,879 \\
Perceived Value & 0,918 \\
Store Atmosphere & 0,911 \\
\hline
\end{tabular}

The standard of measurement to assess the convergent validity is by comparing the loading factor greater than 0,7. However, previous researchers (Ertz, Karakas, \& Sarigöllü, 2016; Truong \& McColl, 2011; Chen \& Tsai, 2007) have considered 0,5 as a cut-off for acceptable loadings (Table 9).

Tests on the structural model are measured by looking at the R-square value which is the test of goodness of fit model. The result can be seen in Table 10. Moreover, the result of all hypotheses is significant as shown in Table 11. It indicates a reasonable fit.
Table 9 Cross Loading Results

\begin{tabular}{lrrrr}
\hline & $\begin{array}{c}\text { Behavioral } \\
\text { Intention }\end{array}$ & $\begin{array}{c}\text { Customer } \\
\text { Satisfaction }\end{array}$ & $\begin{array}{c}\text { Perceived } \\
\text { Value }\end{array}$ & $\begin{array}{c}\text { Store } \\
\text { Atmosphere }\end{array}$ \\
\hline BI01 & 0,904 & 0,813 & 0,646 & 0,797 \\
BI02 & 0,887 & 0,821 & 0,683 & 0,818 \\
BI03 & 0,774 & 0,646 & 0,732 & 0,683 \\
BI04 & 0,691 & 0,500 & 0,523 & 0,580 \\
CS01 & 0,626 & 0,829 & 0,642 & 0,646 \\
CS02 & 0,633 & 0,839 & 0,684 & 0,667 \\
CS03 & 0,851 & 0,896 & 0,683 & 0,776 \\
CS04 & 0,813 & 0,859 & 0,654 & 0,815 \\
PV01 & 0,546 & 0,530 & 0,692 & 0,544 \\
PV02 & 0,635 & 0,565 & 0,763 & 0,608 \\
PV03 & 0,615 & 0,598 & 0,738 & 0,577 \\
PV04 & 0,640 & 0,538 & 0,717 & 0,541 \\
PV05 & 0,584 & 0,566 & 0,774 & 0,588 \\
PV08 & 0,573 & 0,624 & 0,734 & 0,662 \\
PV09 & 0,619 & 0,703 & 0,751 & 0,701 \\
PV10 & 0,613 & 0,622 & 0,775 & 0,650 \\
PV11 & 0,523 & 0,526 & 0,669 & 0,499 \\
PV12 & 0,455 & 0,470 & 0,675 & 0,497 \\
PV13 & 0,542 & 0,486 & 0,704 & 0,504 \\
PV14 & 0,492 & 0,463 & 0,695 & 0,465 \\
\hline SA01 & 0,776 & 0,809 & 0,703 & 0,819 \\
\hline & & & & \\
\hline
\end{tabular}


Table 9 Cross Loading Results (continued)

\begin{tabular}{rrrrr}
\hline & $\begin{array}{c}\text { Behavioral } \\
\text { Intention }\end{array}$ & $\begin{array}{c}\text { Customer } \\
\text { Satisfaction }\end{array}$ & $\begin{array}{c}\text { Perceived } \\
\text { Value }\end{array}$ & $\begin{array}{c}\text { Store } \\
\text { Atmosphere }\end{array}$ \\
\hline SA02 & 0,757 & 0,765 & 0,626 & 0,832 \\
SA03 & 0,802 & 0,735 & 0,598 & 0,813 \\
SA04 & 0,833 & 0,781 & 0,637 & 0,829 \\
SA05 & 0,526 & 0,510 & 0,529 & 0,597 \\
SA06 & 0,584 & 0,532 & 0,657 & 0,699 \\
SA07 & 0,632 & 0,588 & 0,695 & 0,722 \\
SA09 & 0,483 & 0,410 & 0,390 & 0,623 \\
SA10 & 0,482 & 0,501 & 0,450 & 0,665 \\
SA11 & 0,500 & 0,520 & 0,474 & 0,679 \\
SA12 & 0,583 & 0,534 & 0,523 & 0,698 \\
\hline
\end{tabular}

Table 10 R-squares

\begin{tabular}{lc}
\hline \multicolumn{1}{c}{ Variable } & R-square \\
\hline Behavioral Intention & 0,836 \\
Customer Satisfaction & 0,756 \\
Perceived Value & 0,630 \\
\hline
\end{tabular}

Table 11 Summary of Hypotheses Results

\begin{tabular}{lcc}
\hline $\begin{array}{c}\text { Hypothesis And } \\
\text { Causal Path }\end{array}$ & $\begin{array}{c}\text { Standardized } \\
\text { Structural } \\
\text { Coefficient }\end{array}$ & $\begin{array}{c}\text { Assessment } \\
(\boldsymbol{p}<\mathbf{0 . 0 1})\end{array}$ \\
\hline $\mathrm{H} 1 \mathrm{SA} \rightarrow \mathrm{PV}$ & 0,228 & Significant \\
$\mathrm{H} 2 \mathrm{SA} \rightarrow \mathrm{CS}$ & 0,082 & Significant \\
$\mathrm{H} 3 \mathrm{SA} \rightarrow \mathrm{BI}$ & 0,048 & Significant \\
$\mathrm{H} 4 \mathrm{PV} \rightarrow \mathrm{CS}$ & 0,033 & Significant \\
$\mathrm{H} 5: \mathrm{PV} \rightarrow \mathrm{BI}$ & 0,021 & Significant \\
$\mathrm{H} 6: \mathrm{CS} \rightarrow \mathrm{BI}$ & 0,036 & Significant \\
\hline
\end{tabular}

Note: store atmosphere (SA), perceived value (PV), customer satisfaction (CS), and behavioral intention (BI).

In considering direct effects on behavioral intention, store atmosphere is the best predictor compared to perceived value and customer satisfaction as presented in Table 12. Moreover, the indirect effects are inclusive. The store atmosphere is the variable that influences behavioral intention the most. This influence stems from the positive relations between the store atmosphere, perceived value, and customer satisfaction.

Then, perceived value plays an important role in behavioral intention directly and indirectly. Indirect effects of perceived value are mostly from the positive contri-bution of customer satisfaction. Moreover, store atmosphere is a strong antecedent of perceived value and, a lesser extent in customer satisfaction.
Table 12 Indirect and Direct Effects on Behavioral Intention

\begin{tabular}{lccc}
\hline & Direct & Indirect & Total \\
\hline $\begin{array}{l}\text { Customer } \\
\text { Satisfaction }\end{array}$ & $\mathbf{0 , 0 3 6}$ & & $\mathbf{0 , 0 4 8}$ \\
CS-BI & 0,036 & & \\
Perceived Value & $\mathbf{0 , 0 2 1}$ & $\mathbf{0 , 0 0 1}$ & $\mathbf{0 , 0 2 2}$ \\
PV-BI & 0,021 & & \\
PV-CS-BI & & 0,001 & \\
Store Atmosphere & $\mathbf{0 , 0 4 8}$ & $\mathbf{0 , 0 0 6}$ & $\mathbf{0 , 0 5 4}$ \\
SA-BI & 0,048 & & \\
SA-CS-BI & & 0,002 & \\
SA-PV-BI & & 0,004 & \\
SA-PV-CS-BI & & 0,000 & \\
\hline
\end{tabular}

Note: store atmosphere (SA), perceived value (PV), customer satisfaction (CS), and behavioral intention (BI).

Based on the results, the first hypothesis (H1) is accepted. The influence of store atmosphere on perceived value is positive and significant. The ambiance of a store is an important component affecting customers' perceived value. This result is consistent with the result of Liu and Jang (2009) and Koshki et al. (2014).

For the second hypothesis (H2), the positive relationship between store atmosphere and customer satisfaction is quite surprising. The result shows that café atmosphere influences behavioral intention. This result contradicts with the previous researchers who agree about the store atmosphere variables having no influence on behavioral intention (Hussain \& Ali, 2015; Manan, 2015).

Next, store atmosphere is found to influence behavioral intention directly. Thus, it supports the third hypothesis (H3). This result indicates that the ambiance of the store triggers the intention of customers to visit the café. It is consistent with previous researchers who identify the relationship between a dining café atmosphere and behavioral intention (Jalil et al., 2016b) and between Chinese resort hotel industry and behavioral intention (Ali \& Amin, 2014).

Moreover, the researchers find that perceived value has significant effects on customer satisfaction. So, the fourth hypothesis (H4) is supported. The finding corresponds to Raji and Zainal (2016) who identified the relationship in a Malaysian upscale restaurant, and Cibro and Hudrasyah (2017) in café in Bandung, Indonesia.

The fifth hypothesis (H5) predicts that perceived value will be related to behavioral intention. As tested, perceived value is significantly and positively associated with behavioral intention. Thus, it is supported. These results concur with the previous findings of Githiri (2017) on Kenyan rated restaurants 
and Basaran and Buyukyilmaz (2015) on fast-food and fast-casual restaurants.

Last, the researchers find that customer satisfaction is significantly related to behavioral intention as it is supported by the research of Ismail, Rose, Tudin, and Dawi (2017). The findings support the sixth hypothesis (H6). Moreover, it proves that the dimensions proposed by previous researchers are also applicable in a different area from food and beverages industry (Banerjee \& Singhania, 2018; Pei \& Ayub, 2015; Puri \& Kumar, 2015).

\section{CONCLUSIONS}

The millennials have grown up dining in quick service and fast casual restaurants, and the industry now faces a new challenge of attracting and engaging these customers. Thus, this research is conducted to examine the effects of store atmosphere and perceived value on customer satisfaction and its impact on behavioral intention. The research explores the role played by the store atmosphere and perceived value in a café to determine customer satisfaction and behavioral intentions. The findings suggest that such store atmosphere and perceived value have significant effects on customers' dining satisfaction. Moreover, customer satisfaction appears to have a significant influence on behavioral intentions in all aspects.

This research also examines how customer satisfaction mediates between the store atmosphere and behavioral intentions. Although the result may relate to the measurement issues, conceptual explanations do exist. Besides, the store atmosphere is important to affect the satisfaction level in a café.

From the practical standpoint, the results of this study will help café operators to understand better the important role that store atmosphere play in retaining customers especially the millennials. Café operators have to seriously consider the millennials as potential target markets as they are the most frequent patrons of all types of restaurants, have enormous purchasing power, and become completely influential on their parents' and friends' purchase decisions.

Last, because the samples used to collect the data is limited, the result cannot be generalized. To ensure external validity, a more comprehensive sample in a broader range of café is needed in further research. An opportunity exists for future research to study specific atmosphere more closely in leisure service settings. An interesting element that has received little research attention will be the effect of the selection of music and entertainment (the choice of background music and home band play in a particular day or night).

\section{REFERENCES}

Agriculture and Agri-Food Canada. (2016). Foodservice profile Indonesia. Retrieved from http://www. agr.gc.ca/resources/prod/Internet-Internet/MISBDGSIM/ATS-SEA/PDF/6769-eng.pdf
Akhamiokhor, S., \& Adanikin, A. (2017). Entrepreneurial Strategies and Small and Medium Scale Enterprises (SMEs) development in Ogun State, Nigeria. International and Public Affairs Journal, 1(1), 34-38.

Ali, F., \& Amin, M. (2014). The influence of physical environment on emotions, customer satisfaction and behavioural intentions in Chinese resort hotel industry. Journal for Global Business Advancement, 7(3), 249-266.

Ali, M. S. I., \& Mubarak, K. M. (2016). Exterior atmospherics and there impact on consumer purchasing behavior at self- serving convenience stores. International Journal of Science and Research, 5(11), 263-268.

Ballantine, P. W., Jack, R., \& Parsons, A. G. (2010). Atmospheric cues and their effect on the hedonic retail experience. International Journal of Retail \& Distribution Management, 38(8), 641-653.

Banerjee, S., \& Singhania, S. (2018). Determinants of customer satisfaction, revisit intentions and word of mouth in the restaurant industry - Study conducted in selective outlets of South Kolkata. International Journal of Business and Management Invention (IJBM), 7(6), 63-72.

Basaran, U., \& Buyukyilmaz, O. (2015). The effects of utilitarian and hedonic values on young consumers satisfaction and behavioral intentions. Eurasian Journal of Business and Economics, 8(16), 1-18.

Belás, J., \& Gabčová, L. (2016). The relationship among customer satisfaction, loyalty and financial performance of commercial banks. E a M: Ekonomie a Management, 19(1), 132-147.

Chen, C. F., \& Tsai, D. (2007). How destination image and evaluative factors affect behavioral intentions? Tourism Management, 28(4), 1115-1122.

Chen, M., Zhang, H., Liu, W., \& Zhang, W. (2014). The global pattern of urbanization and economic growth: Evidence from the last three decades. PloS One, 9(8), 1-15.

Cho, J. Y., \& Lee, E. J. (2017). Impact of interior colors in retail store atmosphere on consumers' perceived store luxury, emotions, and preference. Clothing and Textiles Research Journal, 35(1), 33-48.

Cibro, Y. E. B., \& Hudrasyah, H. (2017). Factors that influence customer's intentions to revisit café: Case study of Siete Café in Bandung. Journal of Business and Management, 6(2), 284-300.

Cohen, B., \& Muñoz, P. (2015). Toward a theory of purposedriven urban entrepreneurship. Organization \& Environment, 28(3), 264-285.

Cottet, P., Plichon, V., \& Lichtle, M. C. (2010). The influence of ambient factors in services: The compared effects of perceived colors and store layout. In The $11^{\text {th }}$ International Research Seminar in Service Management.

DeVaney, S. A. (2015). Understanding the millennial generation. Journal of Financial Service Professionals, 69(6), 11-14.

Dibley, A., Clark, M., \& Myers, A. (2016). Emerging trends in customer management in a changing world. Journal of Emerging Trends in Marketing Management, 1(2016), 130-140. 
Ellen, C., Anantadjaya, S. P., \& Saroso, T. (2014). Determinants of entrepreneurial success on Indonesian food service MSMEs. RIBER: Review of Integrative Business \& Economics Research, 3(1), 81-98.

El-Sherie, T. A. E. F., \& Ghanem, M. S. (2016). Free wi-wi service as a competitive advantage in public cafés. International Journal of Heritage, Tourism, and Hospitality, 8(1), 233-248.

Ertz, M., Karakas, F., \& Sarigöllü, E. (2016). Exploring proenvironmental behaviors of consumers: An analysis of contextual factors, attitude, and behaviors. Journal of Business Research, 69(10), 3971-3980.

Fishbein, M., \& Ajzen, I. (1975). Belief, attitude, intention, and behavior: An introduction to theory and research. Reading, MA: Addison-Wesley.

Ghozali, I., \& Latan, H. (2015). Partial Least Squares, konsep, teknik dan aplikasi menggunakan program Smartpls 3.0 untuk penelitian empiris. Semarang: Badan Penerbit UNDIP.

Githiri, M. N. (2017). Influence of physical environment on customer satisfaction and return intention in Kenyan rated restaurants. Asian Journal of Social Science Studies, 2(1), 11-19.

Gogoi, B. J. (2017). Effect of store design on perceived crowding and impulse buying behavior. International Review of Management and Marketing, 7(2), 180186.

Hair, J. F., Hult, G. T. M., Ringle, C. M., \& Sarstedt, M. (2016). A Primer on Partial Least Squares Structural Equation Modeling (PLS-SEM). Thousand Oaks: Sage.

Heung, V. C., \& Gu, T. (2012). Influence of restaurant atmospherics on patron satisfaction and behavioral intentions. International Journal of Hospitality Management, 31(4), 1167-1177.

Hussain, R., \& Ali, M. (2015). Effect of store atmosphere on consumer purchase intention. International Journal of Marketing Studies, 7(2), 35-43.

Indonesia Investments. (2016). General economic outline of Indonesia. Retrieved from https://www.indonesiainvestments.com/culture/economy/generaleconomic-outline/item 251 ?

Ismail, A., Rose, I. R., Tudin, R., \& Dawi, N. M. (2017). Relationship between service quality and behavioral intentions: The mediating effect of customer satisfaction. Etikonomi, 16(2), 125-144.

Ivkov, M., Blešić, I., Simat, K., Demirović, D., \& Božić, S. (2016). Innovations in the restaurant industry-An exploratory study. Economics of Agriculture, 63(4), 1169-1186.

Jalil, N. A. A., Fikry, A., \& Zainuddin, A. (2016a). E-atmospheric effects on youth intention to revisit a cafe. Procedia Economics and Finance, 37, 497503.

Jalil, N. A. A., Fikry, A., \& Zainuddin, A. (2016b). The impact of store atmospherics, perceived value, and customer satisfaction on behavioural intention. Procedia Economics and Finance, 37, 538-544.

Javanmard, H. (2016). Relationship between store image, customer satisfaction, behavioral intention and fast distribution in retails. Journal of Distribution Science, 14(1), 7-15.

Joung, H. W., Choi, E. K., \& Wang, E. (2016). Effects of perceived quality and perceived value of campus foodservice on customer satisfaction: Moderating role of gender. Journal of Quality Assurance in Hospitality \& Tourism, 17(2), 101-113.

Kim, W., \& Han, H. (2008). Determinants of restaurant customers' loyalty intentions: A mediating effect of relationship quality. Journal of Quality Assurance in Hospitality \& Tourism, 9(3), 219-239.

Koshki, N., Esmaeilpour, H., \& Ardestani, A. S. (2014). The study on the effects of environmental quality, food and restaurant services on mental image of the restaurant, customer perceived value, customer satisfaction and customer behavioral intentions: Case study of Boroujerd's Restaurants. Kuwait Chapter of Arabian Journal of Business and Management Review, 33(10), 1-12.

Kotler, P., \& Armstrong, G. (2014). Principles of marketing. Upper Saddle River, N.J.: Pearson.

Liu, Y., \& Jang, S. S. (2009). The effects of dining atmospherics: An extended Mehrabian-Russell model. International Journal of Hospitality Management, 28(4), 494-503.

Magatef, S. G., \& Tomalieh, E. F. (2015). The impact of customer loyalty programs on customer retention. International Journal of Business and Social Science, 6(8), 78-93.

Manan, F. M. (2015). The influence of retail store characteristics on consumer purchase intention (Case study in Multi Mart Mega Mall Manado). Jurnal Berkala Ilmiah Efisiensi, 15(05), 386-396.

Masri, N., Anuar, F. I., \& Yulia, A. (2017). Influence of Wi-Fi service quality towards tourists' satisfaction and dissemination of tourism experience. Journal of Tourism, Hospitality \& Culinary Arts, 9(2), 383-398.

McCarthy, P. (2003). Urban slums reports: The case of Jakarta, Indonesia. Retrieved from https:/www.ucl. ac.uk/dpu-projects/Global_Report/pdfs/Jakarta.pdf

McGrath, M. C., Aronow, P. M., \& Shotwell, V. (2016). Chocolate scents and product sales: A randomized controlled trial in a Canadian bookstore and café. SpringerPlus, 5(1), 1-6.

Moreno, F. M., Lafuente, J. G., Carreon, F. A., \& Moreno, S. M. (2017). The characterization of the millennials and their buying behavior. International Journal of Marketing Studies, 9(5), 135-144.

Ong, V. (2018). Indonesia foodservice market plating up fresh potential. Retrieved from https:/www.nzte. govt.nz/about/news/blogs/indonesia-fresh-potentialfoodservice

Pei, K. J., \& Ayub, A. B. (2015). Measuring customer satisfaction towards cafeteria services in primary health care setting: A cross-section study among patients and health care providers in Bintulu, Sarawak. Open Access Library Journal, 2(04), 1-11.

Petzer, D., \& Mackay, N. (2014). Dining atmospherics and food and service quality as predictors of customer satisfaction at sit-down restaurants. African Journal of Hospitality, Tourism and Leisure, 3(2), 1-14. 
Puri, G. \& Kumar, M. (2015). Importance of service quality in restaurant operations: A review. International Journal of Business and Administration Research Review, 2(11), 313-318.

Raji, M. N. A., \& Zainal, A. (2016). The effect of customer perceived value on customer satisfaction: A case study of Malay upscale restaurants. GeografiaMalaysian Journal of Society and Space, 12(3), 5868.

Rozekhi, N. A., Hussin, S., Siddiqe, A. S. K. A. R., Rashid, P. D. A., \& Salmi, N. S. (2016). The influence of food quality on customer satisfaction in fine dining restaurant: Case in Penang. International Academic Research Journal of Business and Technology, 2(2), 45-50.

Ryu, K., \& Jang, S. (2008). DINESCAPE: A scale for customers' perception of dining environments. Journal of Foodservice Business Research, 11(1), 2-22.

Ryu, K., Han, H., \& Kim, T. H. (2008). The relationships among overall quick-casual restaurant image, perceived value, customer satisfaction, and behavioral intentions. International Journal of Hospitality Management, 27(3), 459-469.

Sabir, R. I., Irfan, M., Akhtar, N., Pervez, M. A., \& Rehman, A. U. (2014). Customer satisfaction in the restaurant industry; Examining the model in local industry perspective. Journal of Asian Business Strategy, 4(1), 18-31.

Saulo, A. A. (2016). Millennials and food. Food Safety and Technology, 63, 1-3.

Shin, C. S., Hwang, G. S., Lee, H. W., \& Cho, S. R. (2015). The impact of Korean franchise coffee shop service quality and atmosphere on customer satisfaction and loyalty. The East Asian Journal of Business Management (EAJBM), 5(4), 45-57.

Skandrani, H., Ben Dahmane Mouelhi, N., \& Malek, F. (2011). Effect of store atmospherics on employees' reactions. International Journal of Retail \& Distribution Management, 39(1), 51-67.

Solomon, M., Bamossy, G., Askegaard, S., \& Hogg, M. (2014). Consumer behaviour: A European perspective. Harlow: Pearson Higher Education.

Sweeney, J. C., \& Soutar, G. N. (2001). Consumer perceived value: The development of a multiple item scale. Journal of Retailing, 77(2), 203-220.

Triantafillidou, A., \& Siomkos, G. (2014). Consumption experience outcomes: Satisfaction, nostalgia intensity, word-of-mouth communication and behavioural intentions. Journal of Consumer Marketing, 31(6/7), 526-540.

Truong, Y., \& McColl, R. (2011). Intrinsic motivations, self-esteem, and luxury goods consumption. Journal of Retailing and Consumer Services, 18(6), 555-561.

Tulipa, D., Gunawan, S., \& Supit, V. H. (2014). The influence of store atmosphere on emotional responses and re-purchase intentions. Business Management and Strategy, 5(2), 151-164.

Wade, R., Holmes, M. R., \& Gibbs, C. (2017). The challenges of full-service restaurant brand internationalization: A United States/Canada perspective. Journal of Foodservice Business Research, 21(2), 139-153.

Wahyuningsih, W. (2011). Customer value, satisfaction and behavioral intentions: The effects of consumer search behavior. ASEAN Marketing Journal, 3(1), $1-20$. 